\title{
SOME FACTORS AFFECTING DESIGN OF A FURNITURE CALORIMETER HOOD AND EXHAUST
}

Leonard Y. Cooper

Building and Fire Research Laboratory

Gaithersburg, Maryland 20899

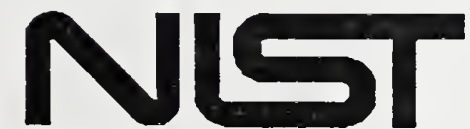

United States Department of Commerce chnology Administration

$Q C$ utional Institute of Standards and Technology

100

.456

\#5298

1993 

NISTIR 5298

\section{SOME FACTORS AFFECTING THE DESIGN OF A FURNITURE CALORIMETER HOOD AND EXHAUST}

Leonard Y. Cooper

December 1993

Building and Fire Research Laboratory

National Institute of Standards and Technology

Gaithersburg, MD 20899

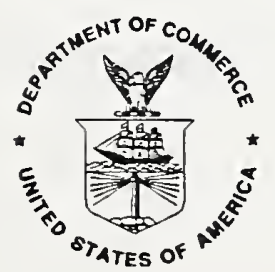

U.S. Department of Commerce

Ronald H. Brown, Secretary

Technology Administration

Mary L. Good, Under Secretary for Technology

National Institute of Standards and Technology

Arati Prabhakar, Director 

TABLE OF CONTENTS

Page

TABLE OF CONTENTS $\ldots \ldots \ldots \ldots \ldots \ldots \ldots \ldots \ldots \ldots \ldots \ldots \ldots \ldots \ldots$

LIST OF FIGURES $\ldots \ldots \ldots \ldots \ldots \ldots \ldots \ldots \ldots \ldots \ldots \ldots \ldots \ldots \ldots \ldots \ldots \ldots \ldots$

ABSTRACT $\ldots \ldots \ldots \ldots \ldots \ldots \ldots \ldots \ldots \ldots \ldots \ldots \ldots \ldots \ldots \ldots \ldots \ldots \ldots \ldots \ldots$

PURPOSE OF THE FURNITURE CALORIMETER; DESIGN FUNCTIONS; AND SOME

INHERENT LIMITATIONS OF A PARTICULAR DESIGN $\ldots \ldots \ldots \ldots \ldots \ldots \ldots$

INTERACTIONS BETWEEN THE HOOD, THE FIRE, AND ITS PLUME; DESIGNING TO

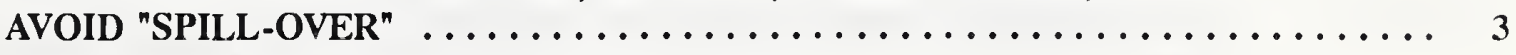

Basic Phenomena; Criteria to Avoid Spill-Over .................. 3

Flame Length; Plume Mass Flow Rate and Temperature . . . . . . . . . . . 5

Using the Point Source Plume for Elevations Above the Flame $\ldots \ldots \ldots \ldots \ldots \ldots$

An Estimate of Required Side-Wall Depth ................... 8

Required Side-Wall Depth; the Effect of Direct Plume Exhaust $\ldots \ldots \ldots \ldots \ldots$

AN IDEAL DESIGN: HOOD AT FLAME TIP; EXHAUST RATE MATCHES EXACTLY

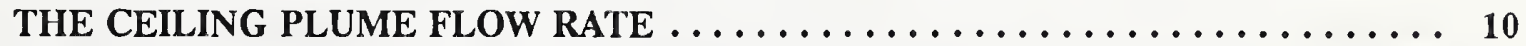

The Adjustable-Hood-Height Feature $\ldots \ldots \ldots \ldots \ldots \ldots \ldots \ldots \ldots \ldots \ldots$

Achieving and Implementing the Adjustable-Hood-Exhaust-Flow Feature $\ldots \ldots \ldots 11$

THE ASSUMPTION OF A CENTERED HOOD DUCT INLET $\ldots \ldots \ldots \ldots \ldots \ldots \ldots \ldots$

GENERAL RESULTS AND GUIDELINES; GENERAL CONCLUSIONS;

RECOMMENDATIONS FOR IMPROVEMENTS TO THE NIST BUILDING 205

FURNITURE CALORIMETER . . . . . . . . . . . . . . . . 12

General Results and Guidelines . . . . . . . . . . . . . . . . . . . . 12

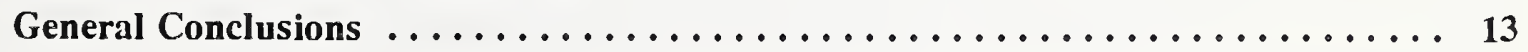

ACKNOWLEDGEMENTS $\ldots \ldots \ldots \ldots \ldots \ldots \ldots \ldots \ldots \ldots \ldots \ldots \ldots \ldots \ldots$

NOMENCLATURE $\ldots \ldots \ldots \ldots \ldots \ldots \ldots \ldots \ldots \ldots \ldots \ldots \ldots \ldots \ldots \ldots \ldots \ldots$

REFERENCES $\ldots \ldots \ldots \ldots \ldots \ldots \ldots \ldots \ldots \ldots \ldots \ldots \ldots \ldots \ldots \ldots \ldots \ldots \ldots \ldots \ldots$ 


\section{LIST OF FIGURES}

Page

Figure 1. Interactions between the hood components, the fire and its plume $\ldots \ldots \ldots 16$

Figure 2. $\quad$ Plots of $L_{F L A M E} v s\left(1-\lambda_{R}\right) \dot{Q}$ for different $D_{F I R E}$; from Eq. (7). . . . . . 17

Figure 3. Plots of $\dot{V}_{\mathrm{P}}$ vs $\left(\mathrm{z}-\mathrm{z}_{\mathrm{FIRE}}\right)>\mathrm{L}_{\mathrm{FLAME}}$ for $\left(1-\lambda_{\mathrm{R}}\right) \dot{\mathrm{Q}}=200 \mathrm{~kW}$ and for different

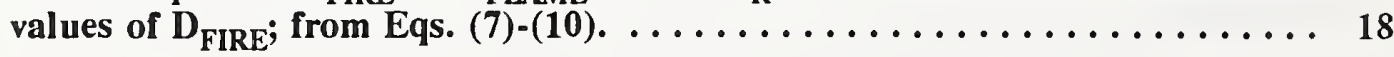

Figure 4. Plots of $\dot{\mathrm{V}}_{\mathrm{P}}$ vs $\left(\mathrm{z}-\mathrm{z}_{\mathrm{FIRE}}\right)$, where $\mathrm{T}_{\mathrm{P}, \mathrm{MAX}} \leq \mathrm{T}_{\mathrm{AMB}}+500 \mathrm{~K}$ for different values of $\left(1-\lambda_{R}\right) \dot{Q}$; from the point source plume model of Eqs. (10), (12), and (13)

Figure 5. A possible implementation of the ideal hood design concept with variable- $\mathrm{C}_{\mathrm{CEIL}}$ and

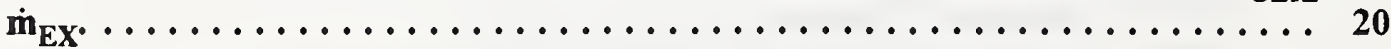

Figure 6. Sketch of the flow for an off-center plume in hoods with identical depth and span and with adequate $\dot{\mathrm{m}}_{\mathrm{EX}} / \dot{\mathrm{m}}_{\mathrm{P}, \mathrm{CEIL}}>1$ to achieve full exhaust of the plume flow, without a smoke-layer: left - horizontal hood ceiling with sidewalls; right - conical hood. 


\title{
SOME FACTORS AFFECTING THE DESIGN OF A FURNITURE CALORIMETER HOOD AND EXHAUST
}

\author{
Leonard Y. Cooper \\ Fire Modeling Group \\ Building and Fire Research Laboratory \\ National Institute of Standards and Technology
}

\begin{abstract}
This work considers factors affecting the design of an effective and versatile furniture calorimeter hood and exhaust system. The purpose of the furniture calorimeter, design functions, and inherent limitations of a particular design are discussed. The interactions between the hood structure and the fire and its plume are analyzed in the context of avoiding: flame impingement on the hood; enhanced combustion of a test article, over and above that of a free-burn; loss of combustion product plume gases due to "spill-over" below the hood; and unacceptable dilution of plume gases in the measurement section of the exhaust duct. The concept of the ideally designed hood is introduced, where, throughout the course of the burn of a test article the hood is always immediately above the flame tip and the exhaust rate always exactly matches the hood-ceiling-elevation plume-flow rate. Methods to partially or completely achieve the ideal design are presented. These include the combined features of adjustable hood elevation and adjustable hood exhaust rate.

The ideas and results of analyses developed are applied in examples relevant to the existing furniture calorimeter hood and exhaust system of the NIST Building 205 Fire Research Laboratory. Recommendations for improvements to this facility are presented.
\end{abstract}

Keywords: buoyant plumes, calorimeters, exhaust systems, fire plumes, flame length, furniture calorimeter, wall flows 


\section{I'URPOSE OF THE FURNITURE CALORIMETER; DESIGN FUNCTIONS; AND SOME INHERENT LIMITATIONS OF A PARTICULAR DESIGN}

The combustion product collector or calorimeter hood device is a basic instrument of a fire research laboratory. It is used to study the combustion characteristics of idealized and practical arrays of combustibles under "free burn" conditions, i.e., burning in spaces which are so large and/or so effectively ventilated that for times of interest the burn characteristics of the fuel array are substantially unaffected by the bounding surfaces of the facility that contains the combustibles and/or by any deviations from quiescent, uncontaminated, ambient-temperature air environment that may exist near the combustion zone.

The calorimeter hoods to be considered here are those which include the design feature of a fandriven exhaust flow through a duct in the center of the hood. The duct flow rate that would be determined from known exhaust fan characteristics will always be assumed to dominate purely buoyancy-driven flow enhancements.

There are two basic functions of the collector hood and its components:

1. to collect the combustion products during the entire course of a test and to transport and safely dispose of them outside of the laboratory;

2. to measure the characteristics of the combustion products collected by the hood and exhausted through the hood duct, in order to quantify the energy release rate of the fire and the type and rate of products of combustion generated.

Any particular hood design is limited inevitably in its range of use (i.e in the range of combustible arrays it can be used to study safely under free burn conditions) by at least four factors:

1. ability to extract all products of combustion from the laboratory through the hood duct without significant (from the point of view of loss of products of combustion to be measured, or threat of contamination of the laboratory environment) spill-over;

2. the ability to keep the overhead gas smoke temperatures and/or ceiling- or curtainsurface temperatures low enough so that radiation feedback to the fuel array will not be so large as to result in "enhanced burning" (a non-free-burn characteristic);

3. the hood must be elevated enough above the burning combustibles so that the flames do not contact the hood surfaces or enter the hood duct (a non-free-burn characteristic); and

4. in terms of useful measurements of energy release rate (from oxygen consumption calorimetry) or generation rate of products, the hood should not be so high above the combustion zone, or the amount of outside air that is otherwise mixed with the exhaust should not be so great that excessive dilution of products precludes measurement of their concentrations to satisfactory accuracy.

In terms of a possible guaranteed-free-burn design rule, "the more elevated the hood the better," note that factor 1 and 4 above argue for the lowest possible hood, while factors 2 and 3 argue for the most elevated possible hood. 
Note that layer build-up in a hood adds potentially significant unsteadiness and time delay which distort measurements of, e.g., rate of heat release vs time.

Before a test is actually carried out one does not generally know whether a particular hood design is suitable for the evaluation of a particular combustible. This is true since the burn characteristics, e.g., energy release rate, effective elevation and (equivalent "pool") area/diameter of the combustion zone (needed to estimate flame length and plume flow rates and temperatures at the hood/ductentrance elevation), are a priori unknown.

It is the purpose of this memorandum to study the above issues and to provide recommendations and guidelines for the design of a successful furniture calorimeter hood and exhaust systems.

\section{INTERACTIONS BETWEEN THE HOOD, THE FIRE, AND ITS PLUME; DESIGNING TO AVOID} "SPILL-OVER"

\section{Basic Phenomena; Criteria to Avoid Spill-Over}

The hood's ceiling surface and side-wall skirts, and the duct and its exhaust flow rate involve a variety of interactions with the fire and/or the fire plume. These interactions, analogous to interactions between a fire contained in an enclosed space and the upper surfaces of that space [1], are depicted in Figure 1.

The combustion zone itself always interacts with the ceiling and side-walls by way of radiation heat transfer exchanges. A possibly significant aspect of this (in terms of hood-surface-to-fire interactions) is the radiant heating of the exposed ceiling and side-wall surfaces by the high-temperature pyrolyzing surfaces and burning gases of the combustion zone. The radiation absorbed by the hood surfaces can be estimated by assuming that they are totally-absorbing black surfaces being irradiated by a radiating point source (the combustion zone) with strength $\lambda_{\mathrm{R}} \mathrm{Q}$. Here, $\mathrm{Q}$ is the total instantaneous energy release rate of the fire, and $\lambda_{R}$ is typically of the order of 0.35 .

If the hood surfaces are well insulated and the above-mentioned radiation flux from the fire to these surfaces is large enough to yield relatively-high exposed-surface temperatures, in excess, say, of 700 $800 \mathrm{~K}$, then the re-radiation from the ceiling and side-wall surfaces of the hood to the pyrolyzing surfaces can lead to unacceptable enhanced burning of the combustibles. This can only occur if the solid angle defined by the combustion zone and the hood surfaces is a significant fraction of the total solid angle between the combustion zone and its surroundings.

The portion of the fire energy release rate that is not radiated from the combustion zone, $\left(1-\lambda_{R}\right) \dot{Q}$, is convected away with the buoyant high-temperature gases as they flow upward from the combustion zone. These are driven toward the hood ceiling, entraining ambient air laterally along the way. Thus, a plume of upward-moving elevated-temperature gases, a mixture of all the products of combustion plus entrained air, is formed above the fire.

The hot plume gases impinge on the hood ceiling in the vicinity of the duct. There, the hood duct fan exhausts all or a fraction of the total plume mass flow rate. If all of the plume gases are not exhausted the remaining amount turns and spreads out radially across the ceiling surface in a relatively high-temperature, high-velocity, ceiling jet. The ceiling jet traverses the hood ceiling, with convective heat transfer taking place between the gas and the exposed solid surface [2]. 
When the ceiling jet reaches the side walls it impinges on these surfaces and turns downward. A downward-directed wall jet is initiated [3] and there are associated convective heat transfer exchanges between the gas and the exposed side-wall surfaces [4]. The wall jet is of higher temperature and lower density than the smoke layer or ambient air into which it is being driven. It is therefore retarded in its descent mainly by the force of buoyancy. Away from the wall surface, material sheds from the wall-jet boundary flow and this flows back up to the ceiling as an upward-buoyant line-type wall plume, outside and adjacent to the downward wall jet. In its ascent, the wall plume entrains farfield gases laterally. When these wall-plume gases first approach the ceiling they quickly fill the hood collector to some quasi-steady depth, even as the hood exhaust continues to extract a portion of the primary plume flow. A quasi-steady smoke layer in the hood is established.

As a result of the shedding from the downward wall jet, at some distance below the ceiling its mass flow rate is reduced to zero. This is the penetration distance, $\delta_{\mathrm{WJ}}$, of the jet. Let $\delta_{\mathrm{SW}}$ be the depth of the sidewalls. If the hood is to contain and exhaust all products of combustion, without any spillover, it is clear that

$$
\delta_{\mathrm{SW}} \geq \delta_{\mathrm{WJ}}
$$

Let $\delta_{\text {LAY }}$ be the depth of the smoke layer in the hood. Then, in terms of a steady- or quasi-steadystate test scenario, the value of $\delta_{\mathrm{LAY}}$ will be that value which leads to fire-plume and wall-plume rates of inflow to the layer, $\dot{\mathrm{m}}_{\mathrm{P}}$ and $\dot{\mathrm{m}}_{\mathrm{WP}}$, respectively, which together exactly balance the mass flow rate of the hood exhaust, $\dot{\mathrm{m}}_{\mathrm{EX}}$, i.e.,

$$
\dot{\mathrm{m}}_{\mathrm{EX}}=\dot{\mathrm{m}}_{\mathrm{P}}+\dot{\mathrm{m}}_{\mathrm{WP}}
$$

Note that under quasi-steady conditions, if $\delta_{\mathrm{LAY}}$ is increased, both $\dot{\mathrm{m}}_{\mathrm{P}}$ and $\dot{\mathrm{m}}_{\mathrm{WP}}$ are decreased. Indeed, if the layer submerges the wall jet completely, then $\dot{\mathrm{m}}_{\mathrm{WP}}=0$ and all the above-described wall-jet/wall-plume flow activity occurs entirely within the smoke layer itself. Therefore, as expected, the smaller the value of $\dot{m}_{\mathrm{EX}}$, the larger the value of $\delta_{\mathrm{LAY}}$.

If the hood is to contain and exhaust all products of combustion, without any spill-over, then, in addition to the criterion of Eq. (1), it is clear that

$$
\delta_{\text {SW }} \geq \delta_{\text {LAY }}
$$

If the smoke layer is opaque and relatively thick, say $\delta_{\mathrm{LAY}}$ is of the order of $1 \mathrm{~m}$, and is at a relatively high temperature, in excess, say, of $700-800 \mathrm{~K}$, then, as in the above-mentioned case of high hood surface re-radiation, the re-radiation from the gas layer to the burning surfaces can lead to unacceptable enhanced burning of the combustibles. Again, this will only occur if the solid angle defined by the combustion zone and the lower smoke layer interface is relatively large.

Even if the layer is thin and gas radiation leading to enhanced burning is not a problem, water cooling of the radiation-exposed hood surfaces should be provided when possible. This is especially true near the duct entrance region where intermittent flame impingement can be anticipated, even 
under ideal conditions. Cooling of the hood will limit the possible threat of significant radiation feedback to the combustible, leading to enhanced burning. It will also provide for a clurable hood structure.

\section{Flame Length; Plume Mass Flow Rate and Temperature}

To insure free-burn test characteristics, the top of the flames must not touch the ceiling surface. To estimate flame length, and thereby determine the suitability of a particular hood design to test a particular class of combustible, it is necessary to characterize the effective elevation, $z_{F I R E}$, and diameter, $\mathrm{D}_{\text {FIRE }}$, of its fire. To do this for geometrically complicated combustibles, like furniture items, and to do so when even qualitative burn characteristics are unavailable, it seems reasonable that one to two $\left(z_{\text {FIRE }}, D_{\text {FIRE }}\right)$ pairs should be considered. The following pair is always recommended:

A $z_{\text {FRE }}$ value which is characteristic of the elevations of the surfaces of the item in its virgin, unburned state. For example, in the case of tables, $\mathrm{z}_{\mathrm{FIRE}}$, would be the elevation of the table top; in the case of chairs, the elevation of the top of the seat; in the case of a rectangular slab, the elevation of the top of the slab; etc. A D FIRE is determined from

$$
\pi \mathrm{D}_{\text {FIRE }}^{2}=\text { area of the fire source }
$$

where the area of the fire source is taken to be the plan area of the combustible.

If the materials of construction have a propensity to drip, then the following $\left(z_{F I R E}, D_{F I R E}\right)$ pair should also be considered:

$$
\begin{aligned}
& z_{\text {FIRE }}=z_{\text {PAN }} \\
& \pi D_{\text {FIRE }}^{2}=\text { area of the pan }
\end{aligned}
$$

where $z_{\text {PAN }}$ is the elevation of the pan on which the test item is placed during the burn. Typically, the area of the pan will correspond closely to the plan area of the combustible, and the $\mathrm{D}_{\text {FIRE }}$ of (5) and (6) will be identical.

Based on a specified $\left(\mathrm{z}_{\mathrm{FIRE}}, \mathrm{D}_{\mathrm{FIRE}}\right)$ pair, flame length, $\mathrm{L}_{\text {FLAME}}$, as measured above $\mathrm{z}_{\mathrm{FIRE}}$, can be estimated from [5]

$$
\mathrm{L}_{\mathrm{FLAME}} / \mathrm{m}=\mid \begin{gathered}
0 \quad \text { if } 0.249\left[\left(1-\lambda_{\mathrm{R}}\right) \dot{\mathrm{Q}} / \mathrm{kW}\right]^{2 / 5}-1.02 \mathrm{D}_{\mathrm{FIRE}} / \mathrm{m}<0 \\
0.249\left[\left(1-\lambda_{\mathrm{R}}\right) \dot{\mathrm{Q}} / \mathrm{kW}\right]^{2 / 5}-1.02 \mathrm{D}_{\mathrm{FIRE}} / \mathrm{m} \\
\text { if } 0.249\left[\left(1-\lambda_{\mathrm{R}}\right) \dot{\mathrm{Q}} / \mathrm{kW}\right]^{2 / 5}-1.02 \mathrm{D}_{\mathrm{FIRE}} / \mathrm{m} \geq 0
\end{gathered}
$$


where

$$
\mathrm{z}_{\mathrm{FLAME}}=\mathrm{z}_{\mathrm{FIRE}}+\mathrm{L}_{\mathrm{FLAME}}
$$

corresponds to the elevation which essentially separates the reacting region of the plume, below, from the non-reacting region, above. This is the elevation in the plume where the peak centerline temperature, $\mathrm{T}_{\mathrm{P}, \mathrm{MAX}}$, is approximately $500 \mathrm{~K}$ above the ambient.

Using Eq. (7), $L_{\text {FLAME }}$ vs $\left(1-\lambda_{R}\right) \dot{Q}$ for different $D_{\text {FIRE }}$ were calculated and plotted in Figure 2. These results can be used to estimate the minimum $\mathrm{z}_{\text {CEIL }}$ for a hood that would be used to exhaust and measure combustion products from a free-burn fire of known elevation, $\mathrm{z}_{\mathrm{FIRE}}$, and specified $\mathrm{Q}$ and $\lambda_{\mathrm{R}}$. For example, consider a natural gas burner fire with $\mathrm{D}_{\mathrm{FIRE}}=0.10 \mathrm{~m}$ and $\dot{\mathrm{Q}}=500 \mathrm{~kW}$. Based on [6], it is reasonable to expect $\lambda_{\mathrm{R}}$ to be within the range $0.2<\lambda_{\mathrm{R}}<0.35$, i.e., $325 \leq(1$ $\left.\lambda_{\mathrm{R}}\right) \dot{\mathrm{Q}} / \mathrm{kW} \leq 400$. For this fire, $\mathrm{L}_{\mathrm{FLAME}}$ is estimated from Figure 2 to be in the range $2.4 \mathrm{~m}<\mathrm{L}_{\mathrm{FLAME}}$ $<2.6 \mathrm{~m}$. Therefore, the hood should be no closer to the surface of the burner than $2.6 \mathrm{~m}$. Alternatively, if, as in the present hood in the NIST Building 205 Fire Research Laboratory, the exhaust duct entry is $2.3 \mathrm{~m}$ above the floor (i.e., $\mathrm{z}_{\mathrm{CEIL}}=2.3 \mathrm{~m}$ ) and the burner surface is $0.3 \mathrm{~m}$ above the floor (i.e., $\left.z_{F I R E}=0.3 \mathrm{~m}\right)$, then the maximum allowable $\left(1-\lambda_{R}\right) \dot{\mathrm{Q}},\left(1-\lambda_{\mathrm{R}}\right) \dot{\mathrm{Q}}_{\mathrm{MAX}}$, is that which produces $\mathrm{L}_{\mathrm{FLAME}} \leq 2.0 \mathrm{~m}$. According to Figure $2,\left(1-\lambda_{\mathrm{R}}\right) \mathrm{Q}_{\mathrm{MAX}}=210 \mathrm{~kW}$. Corresponding to the above $\lambda_{\mathrm{R}}$ range, the value of $\dot{Q}$ that will lead to $\mathrm{z}_{\mathrm{FLAME}}=\mathrm{z}_{\mathrm{CEIL}}$ is estimated to be in the range $260 \mathrm{~kW} \leq \dot{\mathrm{Q}} \leq 320 \mathrm{~kW}$.

For elevations, $\mathrm{z}$, at and above $\mathrm{z}_{\mathrm{FLAME}}$, the mass flow rate of the plume, $\dot{\mathrm{m}}_{\mathrm{P}}$ can be estimated from [5]

$$
\begin{aligned}
& \text { For } \mathrm{z}-\mathrm{z}_{\mathrm{FLAME}} \geq 0 \\
& \begin{aligned}
\dot{\mathrm{m}}_{\mathrm{P}} /(\mathrm{kg} / \mathrm{s})= & 0.071\left[\left(1-\lambda_{\mathrm{R}}\right) \dot{\mathrm{Q}} / \mathrm{kW}\right]^{1 / 3}\left\{\left(\mathrm{z}-\mathrm{z}_{\mathrm{FLAME}}\right) / \mathrm{m}+0.166\left[\left(1-\lambda_{\mathrm{R}}\right) \dot{\mathrm{Q}} / \mathrm{kW}\right]^{2 / 5}\right\}^{5 / 3} \\
& \cdot\left[1+0.026\left[\left(1-\lambda_{\mathrm{R}}\right) \dot{\mathrm{Q}}\right]^{2 / 3}\left\{\left(\mathrm{z}-\mathrm{z}_{\mathrm{FLAME}}\right) / \mathrm{m}+0.166\left[\left(1-\lambda_{\mathrm{R}}\right) \dot{\mathrm{Q}} / \mathrm{kW}\right]^{2 / 5}\right\}^{-5 / 3}\right]
\end{aligned}
\end{aligned}
$$

Corresponding to $\dot{\mathrm{m}}_{\mathrm{P}}$, the plume bulk average temperature, $\mathrm{T}_{\mathrm{P}}$, corresponding average density, $\rho_{\mathrm{P}}$, and volume flow rate, $\dot{\mathrm{V}}_{\mathrm{P}}$, can be estimated from

$$
\begin{aligned}
& \mathrm{T}_{\mathrm{P}}-\mathrm{T}_{\mathrm{AMB}}=\left(1-\lambda_{\mathrm{R}}\right) \dot{\mathrm{Q}} /\left(\dot{\mathrm{m}}_{\mathrm{P}} \mathrm{C}_{\mathrm{p}}\right) \\
& \rho_{\mathrm{P}}=\rho_{\mathrm{AMB}} \mathrm{T}_{\mathrm{AMB}} / \mathrm{T}_{\mathrm{P}} \\
& \dot{\mathrm{V}}_{\mathrm{P}}=\dot{\mathrm{m}}_{\mathrm{P}} / \rho_{\mathrm{P}}
\end{aligned}
$$

In an example application of Eqs. (8)-(10), for different values of $D_{\text {FIRE }}, \dot{V}_{P}$ was calculated for $\left(1-\lambda_{\mathrm{R}}\right) \dot{\mathrm{Q}}=200 \mathrm{~kW}$ as a function of $\mathrm{z}-\mathrm{z}_{\mathrm{FIRE}}>\mathrm{L}_{\mathrm{FLAME}}$. The results are presented in Figure 3. From this figure it can be determined, for example, that for a pool fire $2 \mathrm{~m}$ below the Building 205 
hood, i.e., $0.3 \mathrm{~m}$ above the floor, the value of $\dot{V}_{\mathrm{P}, \mathrm{CEIL}}=\dot{\mathrm{V}}_{\mathrm{P}}\left(\mathrm{z}=\mathrm{z}_{\mathrm{CEIL}}\right)$ ranges from $1.5 \mathrm{~m}^{3} / \mathrm{s}$ for $\mathrm{D}_{\text {FIRE }}$ $=0.10 \mathrm{~m}$ to $2.3 \mathrm{~m}^{3} / \mathrm{s}$ for $D_{\text {FIRE }}=1.0 \mathrm{~m}$. Since the present NIST Building 205 hood system can exhaust up to $2.2 \mathrm{~m}^{3} / \mathrm{s}$ (a flow speed of $12 \mathrm{~m} / \mathrm{s}$ through the $0.48 \mathrm{~m}$ diameter duct [7]), the system may be able to (almost) exhaust all of the plume flow for these relatively small fires.

The following property values were used in the calculations of Figure 3, and will be used below in all calculations to follow: $\rho_{\mathrm{AMB}}=1.2 \mathrm{~kg} / \mathrm{m}^{3} ; \mathrm{C}_{\mathrm{p}}=1 \mathrm{kWs} /(\mathrm{kgK}) ; \mathrm{T}_{\mathrm{AMB}}=300 \mathrm{~K}$.

The values of $\dot{m}_{\mathrm{P}}, \mathrm{T}_{\mathrm{P}}, \rho_{\mathrm{P}}$, and $\dot{\mathrm{V}}_{\mathrm{P}}$ at $\mathrm{z}=\mathrm{z}_{\mathrm{FLAME}}$ are designated as $\dot{\mathrm{m}}_{\mathrm{P}, \mathrm{FLAME}}, \mathrm{T}_{\mathrm{P}, \mathrm{FLAME}}, \rho_{\mathrm{P}, \mathrm{FLAME}}$, and $\dot{V}_{\text {P,FLAME }}$, respectively. From Eqs. (9) and (10), these are seen to be independent of $D_{\text {FIRE }}$ and given by

$$
\begin{aligned}
& \dot{\mathrm{m}}_{\mathrm{P}, \mathrm{FLAME}}=0.0054\left(1-\lambda_{\mathrm{R}}\right)(\dot{\mathrm{Q}} / \mathrm{kW}) \mathrm{kg} / \mathrm{s} \\
& \mathrm{T}_{\mathrm{P}, \mathrm{FLAME}}-\mathrm{T}_{\mathrm{AMB}}=1 . /\left[0.0054 \mathrm{C}_{\mathrm{p}} \mathrm{kg} /(\mathrm{kWs})\right] \approx 185 \mathrm{~K} \\
& \rho_{\mathrm{P}, \mathrm{FLAME}} \approx 0.74 \mathrm{~kg} / \mathrm{m}^{3} \\
& \dot{\mathrm{V}}_{\mathrm{P}, \mathrm{FLAME}} \approx 0.0073\left(1-\lambda_{\mathrm{R}}\right)(\dot{\mathrm{Q}} / \mathrm{kW}) \mathrm{m}^{3} / \mathrm{s}
\end{aligned}
$$

As an example application of Eqs. (11) consider the above case of the $\left(1-\lambda_{\mathrm{R}}\right) \dot{\mathrm{Q}}=200 \mathrm{~kW}, 0.10 \mathrm{~m}$ diameter, natural gas fire which was determined to have a $2.0 \mathrm{~m}$ flame length. Eqs. (11) again provides the estimate that $\dot{\mathrm{V}}_{\mathrm{P}, \mathrm{FLAME}}=1.5 \mathrm{~m}^{3} / \mathrm{s}$ for this fire. It is therefore concluded that near the flame tip, for this fire the present capability of the NIST Building 205 hood exhaust system should be adequate to exhaust the entire plume flow.

\section{Using the Point Source Plume for Elevations Above the Flame}

For elevations somewhat above the top of the flame and higher, i.e., above the elevation where $\mathrm{T}_{\mathrm{P}, \mathrm{MAX}}>500 \mathrm{~K}+\mathrm{T}_{\mathrm{AMB}}$, and to a level of accuracy appropriate to certain aspects of hood design analysis, the fire plume can be characterized by the properties of a point-source-driven plume of strength $\left(1-\lambda_{R}\right) \dot{Q}$ [8]. Such properties are independent of $D_{\text {FIRE }}[8]$. For this reason, in the analysis to follow it is more convenient to use the point-source plume description than the description of Eqs. (7)-(10), which does depend on $D_{\text {FIRE- }}$

For $\mathrm{T}_{\mathrm{P}, \mathrm{MAX}}=\mathrm{T}_{\mathrm{AMB}}\left(1+9.1 \dot{\mathrm{Q}}^{* 2 / 3}\right)>500 \mathrm{~K}+\mathrm{T}_{\mathrm{AMB}}$, corresponding to

a) $\quad \dot{\mathrm{Q}}^{*}<\left[\left(500 \mathrm{~K} / \mathrm{T}_{\mathrm{AMB}}\right) / 9.1\right]^{3 / 2} \approx 0.078$; or

b) $\quad \mathrm{z}-\mathrm{z}_{\mathrm{FIRE}}>\left\{\left[9.1\left(1-\lambda_{\mathrm{R}}\right) \dot{\mathrm{Q}}\right] /\left[\rho_{\mathrm{AMB}} \mathrm{C}_{\mathrm{p}}(500 \mathrm{~K}) \mathrm{g}^{1 / 2}\right]\right\}^{2 / 5} \approx 0.12\left[\left(1-\lambda_{\mathrm{R}}\right) \dot{\mathrm{Q}} / \mathrm{kW}\right]^{2 / 5} \mathrm{~m}:$

$$
\begin{aligned}
\dot{\mathrm{m}}_{\mathrm{P}} /(\mathrm{kg} / \mathrm{s}) & =0.21 \rho_{\mathrm{AMB}} \mathrm{g}^{1 / 2}\left(\mathrm{z}-\mathrm{z}_{\mathrm{FIRE}}\right)^{5 / 2} \dot{\mathrm{Q}}^{* 1 / 3} \\
& \approx 0.79\left[\left(\mathrm{z}-\mathrm{z}_{\mathrm{FIRE}}\right) / \mathrm{m}\right]^{5 / 2} \dot{\mathrm{Q}}^{* 1 / 3}
\end{aligned}
$$


where $\mathrm{g}=9.8 \mathrm{~m} / \mathrm{s}^{2}$,

$$
\dot{\mathrm{Q}}^{*}=\left(1-\lambda_{\mathrm{R}}\right) \dot{\mathrm{Q}} /\left[\rho_{\mathrm{AMB}} \mathrm{C}_{\mathrm{p}} \mathrm{T}_{\mathrm{AMB}} \mathrm{g}^{1 / 2}\left(\mathrm{z}-\mathrm{z}_{\mathrm{FIRE}}\right)^{5 / 2}\right] \approx 8.9\left(10^{-4}\right)\left(1-\lambda_{\mathrm{R}}\right)(\dot{\mathrm{Q}} / \mathrm{kW}) /\left[\left(\mathrm{z}-\mathrm{z}_{\mathrm{FIRE}}\right) / \mathrm{m}\right]^{5 / 2}
$$

and where, with the use of Eqs. (10), $T_{\mathrm{P}}, \rho_{\mathrm{P}}$, and $\dot{\mathrm{V}}_{\mathrm{P}}$ can be calculated from Eqs. (12) and (13).

Using Eqs. (10), (12), and (13), values of $\dot{V}_{P}$ vs $\left(1-\lambda_{R}\right) \dot{Q}$ for different $\left(z-z_{F I R E}\right)$ were calculated and plotted in Figure 4. The figure can be used to estimate $\dot{V}_{\mathrm{P}, \mathrm{CEIL}}$, and, therefore, the minimum exhaust flow rate that would avoid any hood filling and spill-over. For example, aside from maximum flame length requirements, it is found from Figure 4 that for the existing hood structure in the NIST Building 205 laboratory, with $\mathrm{z}_{\text {CEIL }}=2.3 \mathrm{~m}$, an increased exhaust capacity, up to approximately $5 \mathrm{~m}^{3} / \mathrm{s}$, is required if the facility is to be able to test pool fires, $0.3 \mathrm{~m}$ above the floor, with convected plume enthalpy flows as high as $1000 \mathrm{~kW}$. Note that for typical values of $\lambda_{\mathrm{R}}=0.35$ or greater, this corresponds to fires with $\dot{Q}$ of $1500 \mathrm{~kW}$ or greater.

\section{An Estimate of Required Side-Wall Depth}

It has been shown in [3] that for room fire scenarios with no directly-overhead plume exhaust (i.e., all ceiling venting is from vents which are removed from the plume/ceiling impingement point), the depth of the wall jet is generally comparable to the fire-to-ceiling distance. In the present application, this suggests that hood side-walls, properly designed according to the criterion of Eq. (1), may obstruct required visualization of the burning test article. Thus, relatively independent of the size of $\mathrm{Q}$, and for "'typical' full-scale fires" with no ceiling flame impingement,

$$
\delta_{\mathrm{WJ}} / \mathrm{H} \approx 0.8 ; \mathrm{H}=\mathrm{z}_{\mathrm{CEIL}}-\mathbf{z}_{\mathrm{FIRE}}
$$

It is also shown in [3], again for room fire scenarios with no directly-centered plume exhaust, that $\dot{\mathrm{m}}_{\mathrm{WP}}$ (for the case of negligible $\delta_{\mathrm{LAY}}$ ) are very large indeed, ten or more times $\dot{\mathrm{m}}_{\mathrm{P}}$.

In view of the above, it is evident that the effect of the hood's direct plume exhaust, which reduces the limiting-large $\delta_{\mathrm{WJ}}$ estimate of Eq. (14), must be taken account of in determining a minimum acceptable design value for side wall depth.

\section{Required Side-Wall Depth; the Effect of Direct Plume Exhaust.}

[In the analysis and discussion to follow it is assumed that the exhaust duct inlet is centered exactly along the plume axis so that, unless the exhaust mass flow is greater than the plume mass flow, $\dot{\mathrm{m}}_{\mathrm{EX}} / \dot{\mathrm{m}}_{\mathrm{P}, \mathrm{CEIL}}>1$, the inlet flow is drawn only from the plume flow (i.e., no component of the inlet flow is drawn asymmetrically from the outside ambient environment). This assumption and its practical implications will be discussed below.] In the immediate region of the plume/ceiling impingement point it is assumed that the hood duct exhausts $\dot{\mathrm{m}}_{\mathrm{EX}}$ of the plume gases. The 
temperature of the exhausted flow is assumed to be equal to the bulk average temperature of the plume at the ceiling elevation, $\mathrm{T}_{\mathrm{P}, \mathrm{CEIL}}=\mathrm{T}_{\mathrm{P}}\left(\mathrm{z}=\mathrm{z}_{\text {CEIL }}\right)$. The remaining flow, has a mass flow rate

$$
\dot{\mathrm{m}}_{\mathrm{EQ}}=\dot{\mathrm{m}}_{\mathrm{P}, \mathrm{CEIL}}\left(1-\dot{\mathrm{m}}_{\mathrm{EX}} / \dot{\mathrm{m}}_{\mathrm{P}, \mathrm{CEIL}}\right)
$$

and average temperature $\mathrm{T}_{\mathrm{P}, \mathrm{CEIL}}$, where $\dot{\mathrm{m}}_{\mathrm{P}, \mathrm{CEIL}}=\dot{\mathrm{m}}_{\mathrm{P}}\left(\mathrm{z}=\mathrm{z}_{\text {CEIL }}\right)$. When it impinges on the ceiling this flow turns horizontally and is assumed to flow radially outward along the exposed surface of the hood ceiling, uniformly distributed in a radially symmetric ceiling jet flow.

We now seek the properties of an equivalent point source of buoyancy of strength $\mathrm{Q}$ (to be determined) located along the original plume axis at an elevation $\mathrm{z}_{\mathrm{EO}}$ (to be determined) where the characteristics of the equivalent source are such that upon impinging on a ceiling surface it will generate the ceiling jet of mass flow rate, $\dot{\mathrm{m}}_{\mathrm{EQ}}$, at average temperature, $\mathrm{T}_{\mathrm{P}, \mathrm{CEIL}}$. From Eqs. (12) and (13) it is found that $z_{\mathrm{EQ}}$ must satisfy

$$
\begin{aligned}
\dot{\mathrm{m}}_{\mathrm{EQ}} & =0.21 \rho_{\mathrm{AMB}} \mathrm{g}^{1 / 2}\left(\mathrm{z}_{\mathrm{CEIL}}-\mathrm{z}_{\mathrm{EQ}}\right)^{5 / 2} \dot{\mathrm{Q}}_{\mathrm{EQ}}^{0}{ }^{1 / 3} \\
\dot{\mathrm{Q}}_{\mathrm{EQ}}^{*} & =\left(1-\lambda_{\mathrm{R}}\right) \dot{\mathrm{Q}} /\left[\rho_{\mathrm{AMB}} \mathrm{C}_{\mathrm{p}} \mathrm{T}_{\mathrm{AMB}} \mathrm{g}^{1 / 2}\left(\mathrm{z}_{\mathrm{CEIL}}-\mathrm{z}_{\mathrm{FIRE}}\right)^{5 / 2}\right] \\
& =\dot{\mathrm{Q}}_{\mathrm{EQ}} /\left[\rho_{\mathrm{AMB}} \mathrm{C}_{\mathrm{p}} \mathrm{T}_{\mathrm{AMB}} \mathrm{g}^{1 / 2}\left(\mathrm{z}_{\mathrm{CEIL}}-\mathrm{z}_{\mathrm{EQ}}\right)^{5 / 2}\right]
\end{aligned}
$$

Solving Eqs. (16) for $\dot{\mathrm{Q}}_{\mathrm{EQ}}$ and $\mathrm{z}_{\mathrm{EQ}}$ leads to

$$
\begin{aligned}
& \left(\mathrm{z}_{\mathrm{CEIL}}-\mathrm{z}_{\mathrm{EQ}}\right) /\left(\mathrm{z}_{\mathrm{CEIL}}-\mathrm{z}_{\mathrm{FIRE}}\right)=\left(1-\dot{\mathrm{m}}_{\mathrm{EX}} / \dot{\mathrm{m}}_{\mathrm{P}, \mathrm{CEIL}}\right)^{2 / 5} \\
& \dot{\mathrm{Q}}_{\mathrm{EQ}} /\left[\left(1-\lambda_{\mathrm{R}}\right) \dot{\mathrm{Q}}\right]=1-\dot{\mathrm{m}}_{\mathrm{EX}} / \dot{\mathrm{m}}_{\mathrm{P}, \mathrm{CEIL}}
\end{aligned}
$$

With the results of Eqs. (17) and (18) it is now possible to estimate the $\delta_{\mathrm{WJ}}$ due to the ceiling jet of the unexhausted plume flow. This is done by simulating the flow as a ceiling jet driven by the plume of the equivalent buoyant point source, and by using Eq. (14) with $\mathrm{H}=\mathrm{z}_{\mathrm{CEIL}}-\mathrm{z}_{\mathrm{EQ}}$.

It is easy to see that even when a significant fraction of plume flow is exhausted, the resulting reduction of $\delta_{\mathrm{WJ}}$ is not large enough to reduce significantly the effect of spill-over in practical hood designs. For example, with $\mathrm{z}_{\mathrm{CEIL}}-\mathrm{z}_{\mathrm{FIRE}}=2 \mathrm{~m}$ and $\dot{\mathrm{m}}_{\mathrm{EX}} / \dot{\mathrm{m}}_{\mathrm{P}, \mathrm{CEIL}}<<1$ (i.e., a relatively small hood exhaust), Eqs. (1), (12), (13), and (14) lead to the likely-unacceptable side-wall length requirement, $\delta_{\mathrm{SW}} \geq \delta_{\mathrm{WJ}} \approx 0.8(2.0 \mathrm{~m})=1.6 \mathrm{~m}$. However, by exhausting, say, 75 percent of $\dot{\mathrm{m}}_{\mathrm{P}, \mathrm{CEIL}}$ the side-wall length requirement is only reduced to $\delta_{\mathrm{SW}} \geq \delta_{\mathrm{WJ}} \approx 0.8(2.0 \mathrm{~m})(1-0.75)^{2 / 5}=0.9 \mathrm{~m}$. It is therefore concluded that a successful hood design, where $\delta_{\mathrm{SW}}$ is no more than a small fraction of $\mathrm{z}_{\mathrm{CEIL}}-\mathrm{z}_{\mathrm{FIRE}}$, requires the duct exhaust flow to exceed the plume flow at the hood ceiling height.

For any particular hood design and burn test item, an exact match between $\dot{\mathrm{m}}_{\mathrm{EX}}$ and $\dot{\mathrm{m}}_{\mathrm{P}, \mathrm{CEIL}}$ would lead to an "ideal" design operating condition in the sense that concentration of products in the hood duct flow would be maximized and, as a result, the highest possible accuracy in their measurement 
could be attained. A higher exhaust rate would lead to further dilution of products in the duct, and a smaller exhaust would lead to hood filling and, possibly, spill-over.

\section{AN IDEAL DESIGN: HOOD A'T FLAME TIP; EXIIAUST RATE MATCHES EXACTLY TIE CEILING PLUME FLOW RATE}

For a hood of specified ceiling height, flame length considerations place an absolute constraint on the test items that can be properly tested in it (see the third of the limiting factors of hood design listed on page 1). Similarly, in contemplating design of a new hood the minimum acceptable value of hood ceiling height would be determined by the expected flame lengths of the class of burn test items for which the facility is being designed.

The following are the characteristics of a hood of ideal design:

1. The hood height is adjustable over the widest possible range. The hood ceiling elevation is always maintained slightly above the flame tip of the free-burning test item (i.e., to maximize product concentration in the plume at the elevation of the exhaust duct while meeting the basic free-burn constraint).

3. The hood exhaust flow rate is adjustable over the widest possible range. The exhaust flow rate is always maintained at the minimum value that completely exhausts the plume flow and eliminates any smoke layer in the hood (i.e., to maximize the product concentration in the duct, thereby yielding the highest possible accuracy in measured energy release and product generation rates.)

These ideal hood features and their implementation are discussed below.

\section{The Adjustable-Hood-Height Feature}

Achieving the adjustable-hood-height feature. The adjustable hood height feature is for the purpose of obtaining control of the fire-to-ceiling distance. Such control can be achieved by raising and lowering either the test item or the hood. Of these two methods, the one involving movement of the test item is the less practical. It would require a platform on which is mounted the burning test item, all photography equipment, and other instruments. It would pose great, and possibly insurmountable difficulties for proper visualization by the test personnel.

A design concept involving raising and lowering the hood is achievable and practical. One possible way to implement the concept is portrayed in Figure 5. The idea is to support the hood by chain or cable from a motor mounted on the ceiling. The centering of the hood above axis of the fire plume would be maintained by guide-cables or guide-rails, much like an elevator. The constraining feature of this concept is that possible leak points upstream of any in-duct measurement station(s) only involve relatively small rates of inflow of ambient air. One possible implementation of the adustableheight hood is depicted in Figure 5. This involves a relatively-large-diameter, high-temperatureresistant, accordion-like, metal duct material.

Implementing the adjustable-hood-height feature. The adjustable-hood-height feature can be implemented in either a technically advanced or a more conservative manner. 
The more conservative implementation involves a test procedure where, based on estimates of the effective values of $D_{\text {FIRE }}(s), z_{F I R E}(s), \lambda_{R}$, and $\dot{Q}$, the test personnel would first determine (e.g., from Figure 2) the maximum flame tip elevation to be expected during the course of the free burn of a specific test item. The hood height would then be set accordingly and fixed for the entire test run.

In using this approach, the hood configuration would be optimized, in principle, at the time of peak flame-tip elevation. However, as mentioned earlier, for practical assemblies of combustibles the ability to make accurate $a$ priori estimates of fire characteristics, and, therefore, of flame tip elevation is usually very limited.

A more advanced implementation of the adjustable-hood-height feature involves a test procedure where hood height adjustments are made during the course of a test burn, with the hood "following" the flame tip as it grows, fluctuates, and then decays. Using the simpler of two possible approaches, hood height corrections would be made manually according to flame-tip visualization by the test personnel. In a more advanced approach, hood height corrections would be made by monitoring flame tip elevation automatically, say with a flame radiation detector, and by providing appropriate automatic feedback control to the hood-support cable motor. Thus, in an optimum way, $\mathrm{z}_{\mathrm{CEIL}}$ would be maintained close to the flame tip, during (most of) the entire test run.

\section{Achieving and Implementing the Adjustable-Hood-Exhaust-Flow Feature}

The adjustable-hood-exhaust-flow feature can be achieved with a variable-speed fan. It can also be achieved with a fixed-speed fan implemented with a duct side-vent having a motor-controlled variable area. Also, the side vent would be combined with an upstream, motor-controlled, duct damper. (The fan/vent/damper system would be located downstream of the duct measurement station.) The purpose of the side vent would be to allow outside air to be drawn to the inlet side of the fan, thereby reducing the portion of the fan inlet flow exhausted through the duct (i.e., reducing $\dot{\mathrm{m}}_{\mathrm{EX}}$ ). With the side vent in a fully open position, the damper would be used to reduce the $\dot{m}_{\mathrm{EX}}$ exhaust flow to arbitrarily small values. This feature would allow testing of relatively-small-Q fires, with correspondingly small values of $\dot{\mathrm{m}}_{\mathrm{P}, \mathrm{CEIL}}$ and $\dot{\mathrm{V}}_{\mathrm{P}, \mathrm{CEIL}}$ at the flame tip elevation.

Of the two systems, the one which uses the fixed-speed fan is depicted in Figure 5.

\section{THE ASSUMPTION OF A CENTERED HOOD DUCT INLET}

It has been assumed above that the exhaust duct inlet of the hood is centered exactly along the plume axis and that, unless $\dot{\mathrm{m}}_{\mathrm{EX}}>\dot{\mathrm{m}}_{\mathrm{P}, \mathrm{CEIL}}$, all flow drawn though the exhaust duct is extracted from the plume flow itself. In practice the plume at the ceiling elevation is never exactly centered. Also, the plume is never exactly rotationally symmetric. Especially if $\dot{\mathrm{m}}_{\mathrm{EX}} \approx \dot{\mathrm{m}}_{\mathrm{P}, \mathrm{CEIL}}$, it is inevitable that some of the mass of material included in $\dot{\mathrm{m}}_{\mathrm{EX}}$ is drawn initially from the quiescent ambient air. Then, the portion of $\dot{\mathrm{m}}_{\text {P,CEIL }}$ not immediately exhausted must flow sideways, producing local ceiling-jet flow activity. This, in turn, leads to some smoke-filling of the hood and possibly some "preferred-direction" spill-over, etc. In general, a complicated three-dimensional, unsteady flow is established near the hood exhaust duct entrance. The characteristics of this flow would be peculiar to the particular burn item being tested, the shape of the hood, etc. 
The undesirable and essentially-unacceptable phenomenon of side-flow leading to spill-over can be eliminated by increasing $\dot{\mathrm{m}}_{\mathrm{EX}} / \dot{\mathrm{m}}_{\mathrm{P}, \mathrm{CEIL}}$. It is also possible that the phenomenon can be suppressed by optimizing the shape of the hood.

In view of the complicated fluid dynamics involved, it is not possible to quantify simply and with full generality the extent to which increases in $\dot{\mathrm{m}}_{\mathrm{EX}}$ are required to eliminate spill-over related to the centered hood/duct-inlet problem for a particular hood design. It is also difficult to quantify the importance of the shape of the hood to the side-movement/spill-over phenomenon. For example, referring to Figure 6, for a given hood depth and span, it is not clear whether a cone-type configuration is to be preferred over a design involving a flat ceiling hood with vertical side vents. (The latter being the basic shape of the present hood in the NIST Building 205 laboratory.)

Prior to the establishment of hood shape guidelines it is necessary to quantify the centered hood/ductinlet problem as it relates to the hood design shape. For an existing hood this can be done quickly and simply with a series of gas burner tests. The objective of such a test program would be to establish the values of $\dot{\mathrm{m}}_{\mathrm{EX}} / \dot{\mathrm{m}}_{\mathrm{P}, \mathrm{CEIL}}$, as a function of $\dot{\mathrm{m}}_{\mathrm{P}, \mathrm{CEIL}},\left(1-\lambda_{\mathrm{R}}\right) \dot{\mathrm{Q}}$, and plume off-set, required to exactly exhaust all of $\dot{m}_{\mathrm{P}, \mathrm{CEIL}}$, or at least to ensure no plume-product spill-over from the hood. Hopefully, it would be determined in such a test program that, for the expected plumes of burning test items for which the hood assembly is being designed, these $\dot{m}_{E X} / \dot{m}_{P, C E I L}$ values are not too much greater than 1. If such is not the case, and if the product-dilution problem is considered significant, then an additional hood-shape design effort would be required prior to the establishment of a successful overall hood/exhaust system design.

\section{GENERAL RESULTS AND GUIDELINES; GENERAL CONCLUSIONS}

\section{General Results and Guidelines}

The following general results and guidelines have been established for the design of a successful combustion product calorimeter hood/collector and exhaust:

1. The elevation of the hood should always be maintained at or above the flame tip [the elevation of the latter is determined from Eq. (7) or Figure 2]. Keeping the hood elevation near the flame tip will make it possible to exhaust the hood at a rate that maximizes the concentrations of products of combustion in the measurement section of the duct, thereby leading to the highest possible accuracy in the measurement of the fires energy release rate and the product generation rates.

2. It is not practical to depend on the depth of hood side-walls to eliminate plume-product spillover from the hood; the elimination of spill-over can be accomplished effectively and economically by increasing the hood exhaust flow rate capability, albeit at the expense of reduction in species concentration at the point of measurement. If this is not possible then the measurement capability of an existing hood should be appropriately "derated," i.e., relative to acceptable test items whose free burn characteristics can be evaluated in the hood facility.

3. The exhaust rate of the hood duct flow, $\dot{\mathrm{m}}_{\mathrm{EX}}$, should be the smallest possible value that would lead to direct extraction all of the flow in the fire plume, $\dot{m}_{P, C E I L}$ [determined from Eq. (9) and Figure 3, or from Eqs. (12) and (13) and Figure 4], i.e., as the plume impinges on the ceiling of the hood at or near the duct entrance. 
4. To accomplish item $3, \dot{\mathrm{m}}_{\mathrm{EX}}$ will always have to exceed $\dot{\mathrm{m}}_{\mathrm{P}, \mathrm{CEIL}}$. For a particular hood design, a determination of $\dot{\mathrm{m}}_{\mathrm{EX}} / \dot{\mathrm{m}}_{\mathrm{P}, \mathrm{CEIL}}$ required to accomplish the exhaust objective of item 3 would require a limited experimental program involving burns with a well-characterized fire source and with known, measured off-sets between the plume and the duct axis. A quality hood design is one which can meet the exhaust criterion of item 3 with values of $\dot{\mathrm{m}}_{\mathrm{EX}} / \dot{\mathrm{m}}_{\mathrm{P}, \mathrm{CEIL}}$ which are not significantly greater than 1 , even when there is a moderate offset between the plume and the duct axes.

5. An ideal hood exhaust design is one that can meet all of the above guidelines continuously, or at least at critical times, during the course of a free-burn test. This can be accomplished, for example, with the use of a hood exhaust system which uses an adjustable-elevation hood collector and a variable-speed fan or a relatively-large-capacity fixed-flow fan (Figure 5) with an adjustable-area side-vent in the duct and an adjustable duct damper, all of which would be located downstream of the duct measurement section.

6. Water cooling of the hood structure should be provided where possible. This will limit the possiblity of significant radiation feedback to and enhanced burning of the combustibles. It will also provide for a more durable hood structure.

\section{General Conclusions}

Prior to actual testing, it is not possible to know the free-burn characteristics of practical test articles to the point that ideal hood/exhaust design parameters can be established. Nevertheless, by use of the proposed methods of continuous manual or automatic control and for relatively broad bounds of test article burn characteristics, the ideal hood/exhaust design concepts proposed here should be capable of providing measurements at near-optimum accuracy throughout most of the test run. The ideal hood/exhaust design concept would yield a versatile test instrument that would be a valuable addition to any fire test laboratory.

\section{ACKNOWLEDGEMENTS}

The author acknowleges gratefully Mr. Emil Braun and Dr. Thomas Ohlemiller for useful discussions on past and current use of the NIST furniture calorimeter and on future needs of this facility.

\section{NOMENCLATURE}

$\begin{array}{ll}C_{p} & \text { specific heat at constant pressure, } 1 \mathrm{kWs} /(\mathrm{kgK}) \\ D_{\text {FIRE }} & \text { effective area of the fire, Fig. } 1 \\ \mathrm{~g} & \text { acceleration of gravity } \\ \mathrm{H} & \text { fire-to-hood distance, Eq. (14) } \\ \text { L FLAME } & \text { flame length, Fig. } 1\end{array}$




\begin{tabular}{|c|c|}
\hline$\dot{\mathrm{m}}$ & mass flow rate \\
\hline$\dot{\mathrm{m}}_{\mathrm{P}}$ & m of plume at elevation of the layer interface, Fig. 1 \\
\hline P,CEIL & $\dot{\mathrm{m}}$ of plume at $\mathrm{z}_{\mathrm{CEIL}}$ \\
\hline$\dot{\mathrm{m}}_{\mathrm{P}, \mathrm{FLAME}}$ & $\dot{\mathrm{m}}$ of plume at $\mathrm{z}_{\mathrm{FLAME}}$ \\
\hline$\dot{\mathrm{m}}_{\mathrm{WP}}$ & m of ambient entrained into wall plume, see Fig. 1 \\
\hline$\dot{\mathrm{m}}_{\mathrm{EQ}}$ & m of equivalent source, Eqs. (15) and (16) \\
\hline$\dot{\mathrm{m}}_{\mathrm{EX}}$ & $\dot{\mathrm{m}}$ of hood exhaust \\
\hline$\dot{\mathrm{Q}}$ & total instantaneous energy release rate of the fire \\
\hline$\dot{\mathrm{Q}}_{\mathrm{EQ}}$ & Q of equivalent source, Eq. (16) \\
\hline$\dot{\mathrm{Q}}^{*}$ & dimensionless Q́, Eq. (13) \\
\hline $\mathrm{T}$ & absolute temperature \\
\hline $\mathrm{T}_{\mathrm{AMB}}$ & $\mathrm{T}$ of ambient, $300 \mathrm{~K}$ \\
\hline $\mathrm{T}_{\mathrm{P}}$ & bulk average $T$ of plume \\
\hline $\mathrm{T}_{\mathrm{P}, \mathrm{CEIL}}$ & $\mathrm{T}_{\mathrm{P}}$ at $\mathrm{z}_{\mathrm{CEIL}}$ \\
\hline $\mathrm{T}_{\mathrm{P}, \mathrm{FLAME}}$ & $\mathrm{T}_{\mathrm{P}}$ at $\mathrm{z}_{\mathrm{FLAME}}$ \\
\hline $\mathrm{T}_{\mathrm{P}, \mathrm{MAX}}$ & peak centerline temperature of the plume \\
\hline$\dot{\mathrm{V}}_{\mathrm{P}}$ & volume flow rate of the plume, Eq. (10) \\
\hline$\dot{\mathrm{V}}_{\mathrm{P}, \mathrm{FLAME}}$ & $\dot{\mathrm{V}}_{\mathrm{P}}$ at $\mathrm{z}_{\mathrm{FLAME}}$ \\
\hline $\mathrm{z}$ & distance above a reference elevation \\
\hline $\mathrm{z}_{\text {CEIL }}$ & $\mathrm{z}$ of hood ceiling, Fig. 1 \\
\hline $\mathrm{z}_{\mathrm{EQ}}$ & $z$ of equivalent source, Eq. (17) \\
\hline $\mathrm{z}_{\text {FIRE }}$ & $z$ of fire, Fig. 1 \\
\hline $\mathrm{z}_{\mathrm{FLAME}}$ & $\mathrm{z}$ of flame tip, Eq. (8), Fig. 1 \\
\hline $\mathrm{z}_{\mathrm{PAN}}$ & $\mathrm{z}$ of pan supporting test item \\
\hline$\delta_{\text {LAY }}$ & depth of the layer interface \\
\hline
\end{tabular}




$\begin{array}{ll}\delta_{\mathrm{SW}} & \text { depth of the sidewalls } \\ \delta_{\mathrm{WJ}} & \text { penetration depth of the wall jet } \\ \lambda_{\mathrm{R}} & \text { fraction of } \mathrm{Q} \text { radiated from the combustion zone } \\ \rho & \text { density } \\ \rho_{\mathrm{AMB}} & \rho \text { of ambient, } 1.2 \mathrm{~kg} / \mathrm{m}^{3} \\ \rho_{\mathrm{P}} & \rho \text { corresponding to } \mathrm{T}_{\mathrm{P}}, \text { Eq. }(10)\end{array}$

\section{REFERENCES}

[1]. Cooper, L.Y., Smoke Movement in Rooms of Fire Involvement and Adjacent Spaces, Fire Safety Journal, 7, pp. 33-46, 1984.

[2]. Cooper, L.Y., Convective Heat Transfer to Ceilings Above Enclosure Fires, 19th Symposium (International) on Combustion, Combustion Institute, pp. 933-939, 1982.

[3]. Cooper, L.Y., Ceiling Jet-Driven Wall Flows in Compartment Fires, Combustion Science and Technology, 62, pp. 285-296, 1988.

[4]. Cooper, L.Y., Heat Transfer in Compartment Fires Near Regions of a Ceiling-Jet Impingement on a Wall, Journal of Heat Transfer, 111, pp. 455-460, 1989.

[5] Heskestad, G., Engineering Relations for Fire Plumes," Fire Safety Journal, 7, pp. 25-32, 1984.

[6] McCaffrey, B.J., Some Measurements of the Radiative Power Output of Diffusion Flames, Proceedings of 1981 Meeting of Western States Section of Combustion Institute, paper WSS/CI 81-15, 1981.

[7] Braun, E., private communication, NIST, Gaithersburg MD, 1993.

[8] Zukoski, E.E., Kubota, T., and Cetegen, B., Entrainment in Fire Plumes, Fire Safety Journal, 3, pp.107-121, 1980/81. 


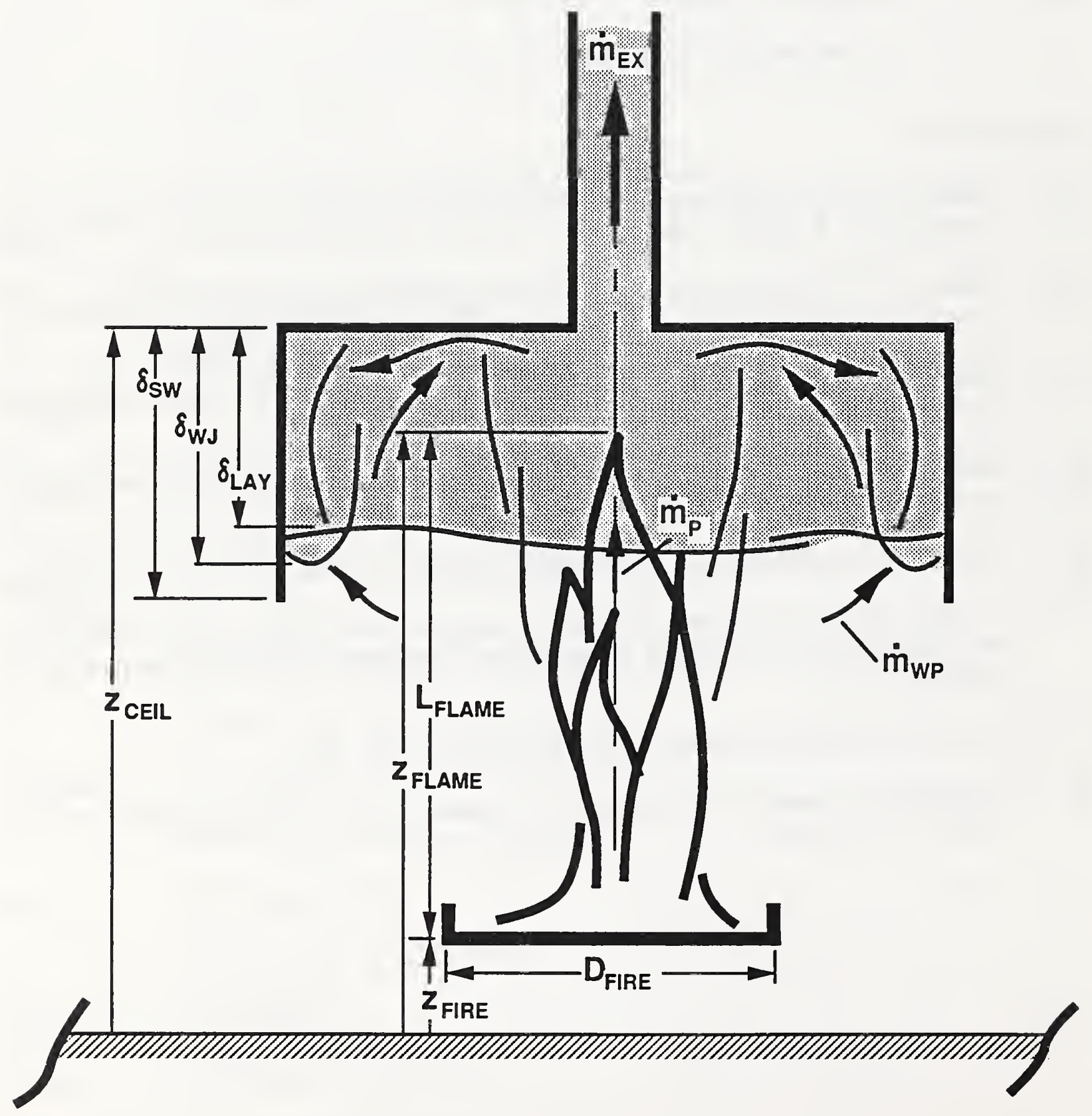

Figure 1. Interactions between the hood components, the fire and its plume. 


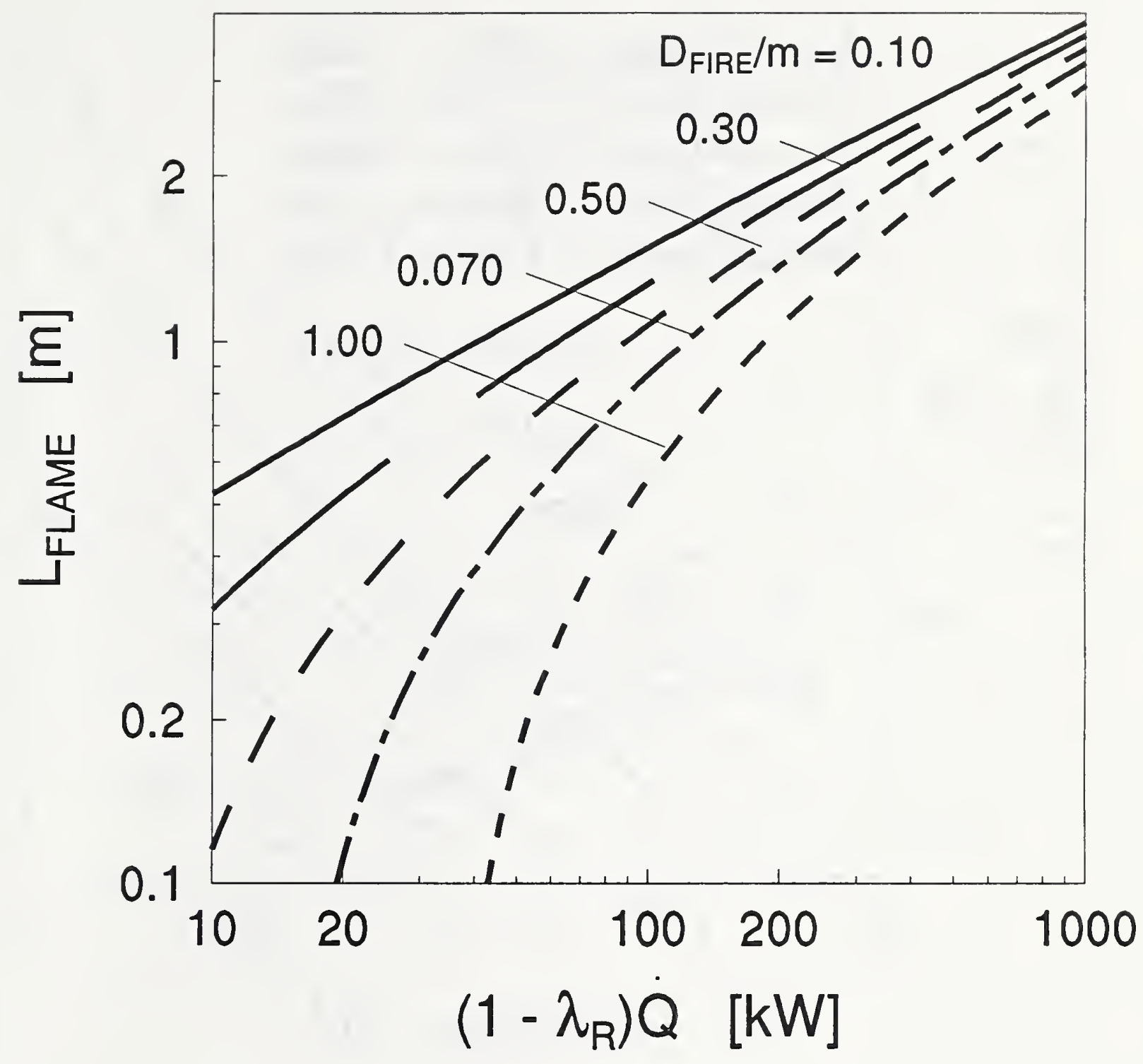

Figure 2. Plots of $L_{\text {FLAME }} v s\left(1-\lambda_{R}\right) \dot{Q}$ for different $D_{\text {FIRE; }}$ from Eq. (7). 


$$
\left(1-\lambda_{R}\right) Q=200 \mathrm{~kW}
$$

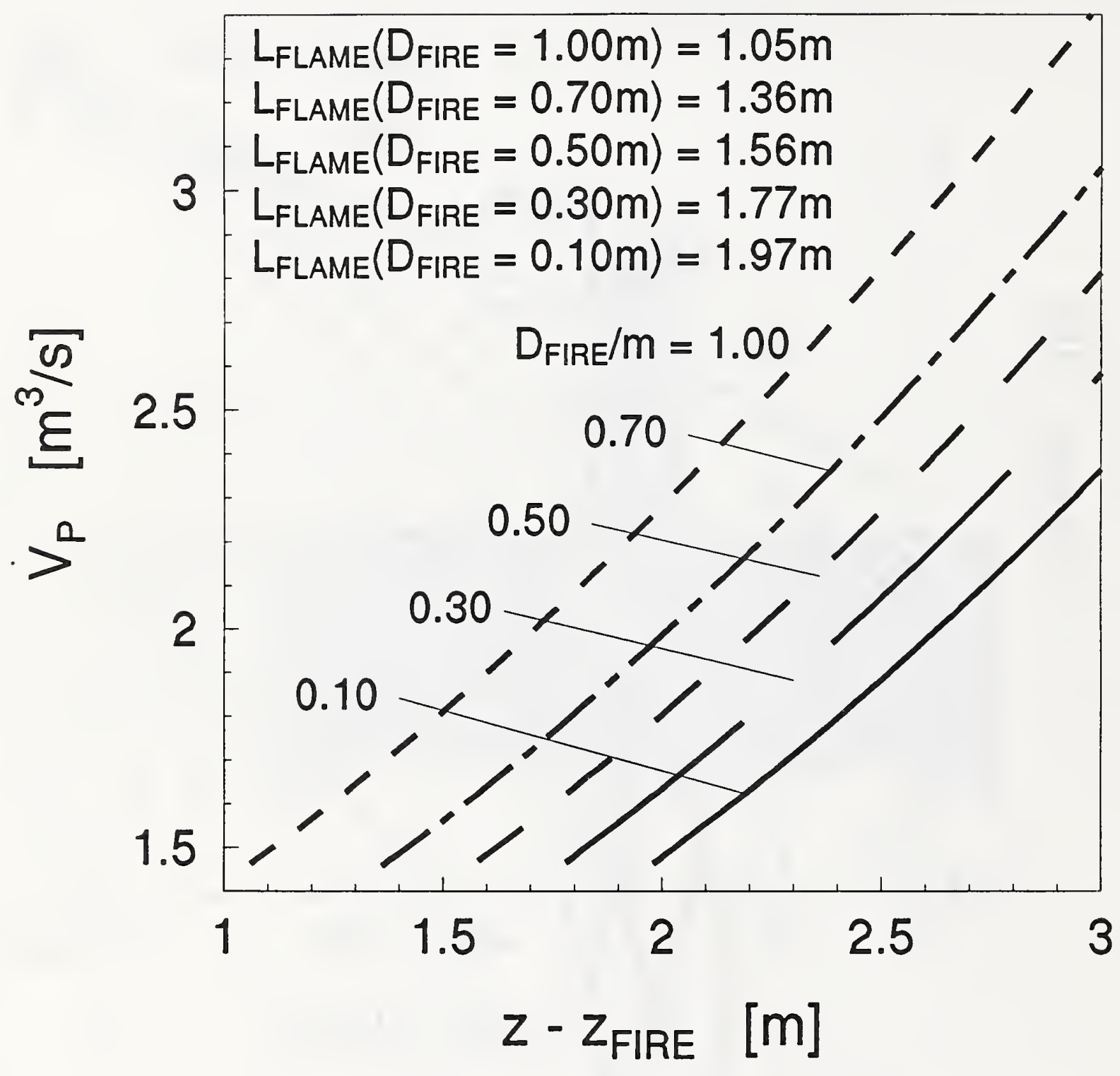

Figure 3. Plots of $\dot{\mathrm{V}}_{\mathrm{P}} \mathrm{vs}\left(\mathrm{z}-\mathrm{z}_{\mathrm{FIRE}}\right)>\mathrm{L}_{\mathrm{FLAME}}$, for $\left(1-\lambda_{\mathrm{R}}\right) \dot{\mathrm{Q}}=200 \mathrm{~kW}$ and for different values of $\mathrm{D}_{\text {FIRE}}$; from Eqs. (7)-(10). 


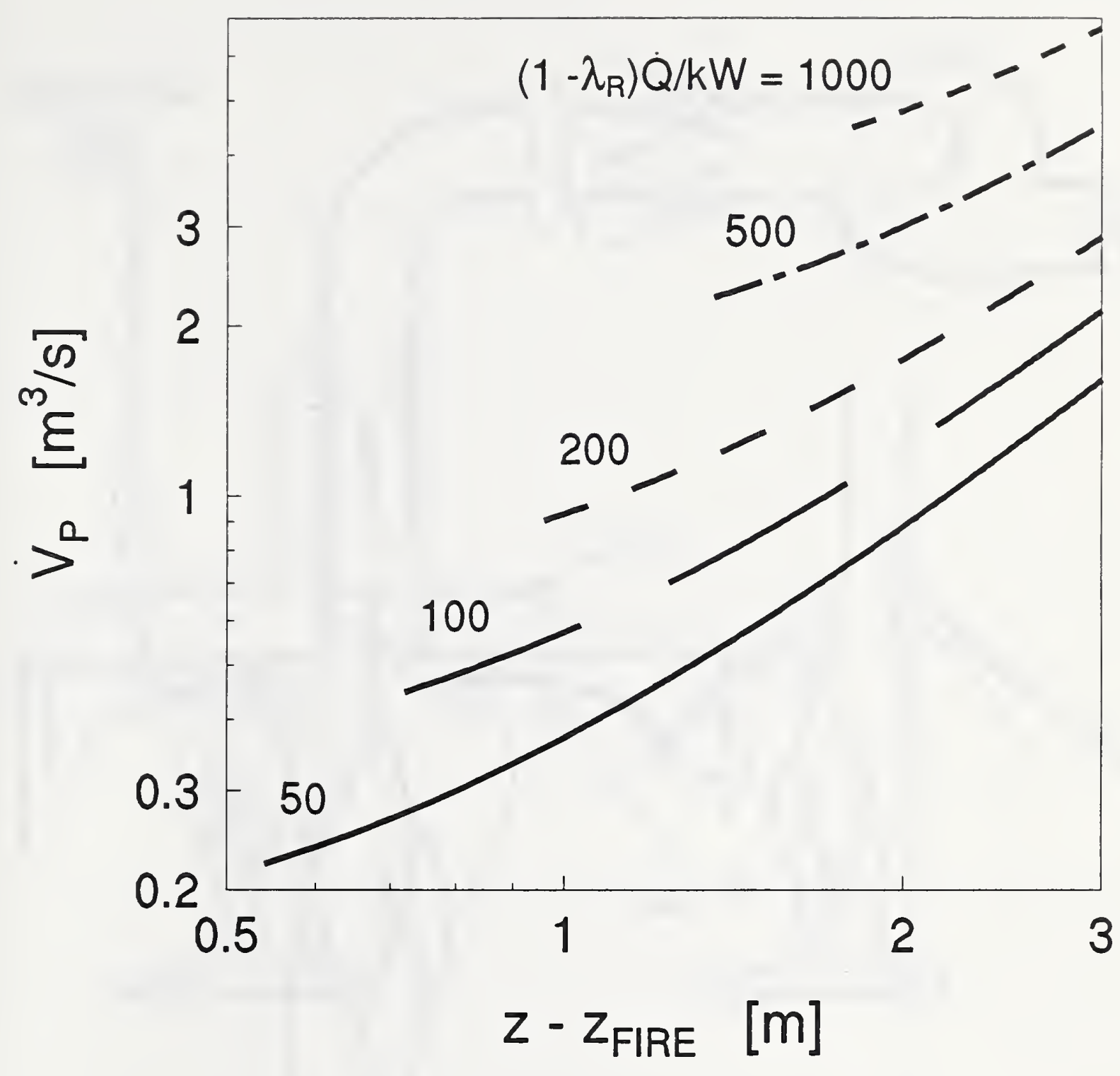

Figure 4. Plots of $\dot{\mathrm{V}}_{\mathrm{P}}$ vs $\left(\mathrm{z}-\mathrm{z}_{\mathrm{FIRE}}\right)$, where $\mathrm{T}_{\mathrm{P}, \mathrm{MAX}} \leq \mathrm{T}_{\mathrm{AMB}}+500 \mathrm{~K}$ for different values of $\left(1-\lambda_{R}\right) \dot{Q} ;$ from the point source plume model of Eqs. (10), (12), and (13). 

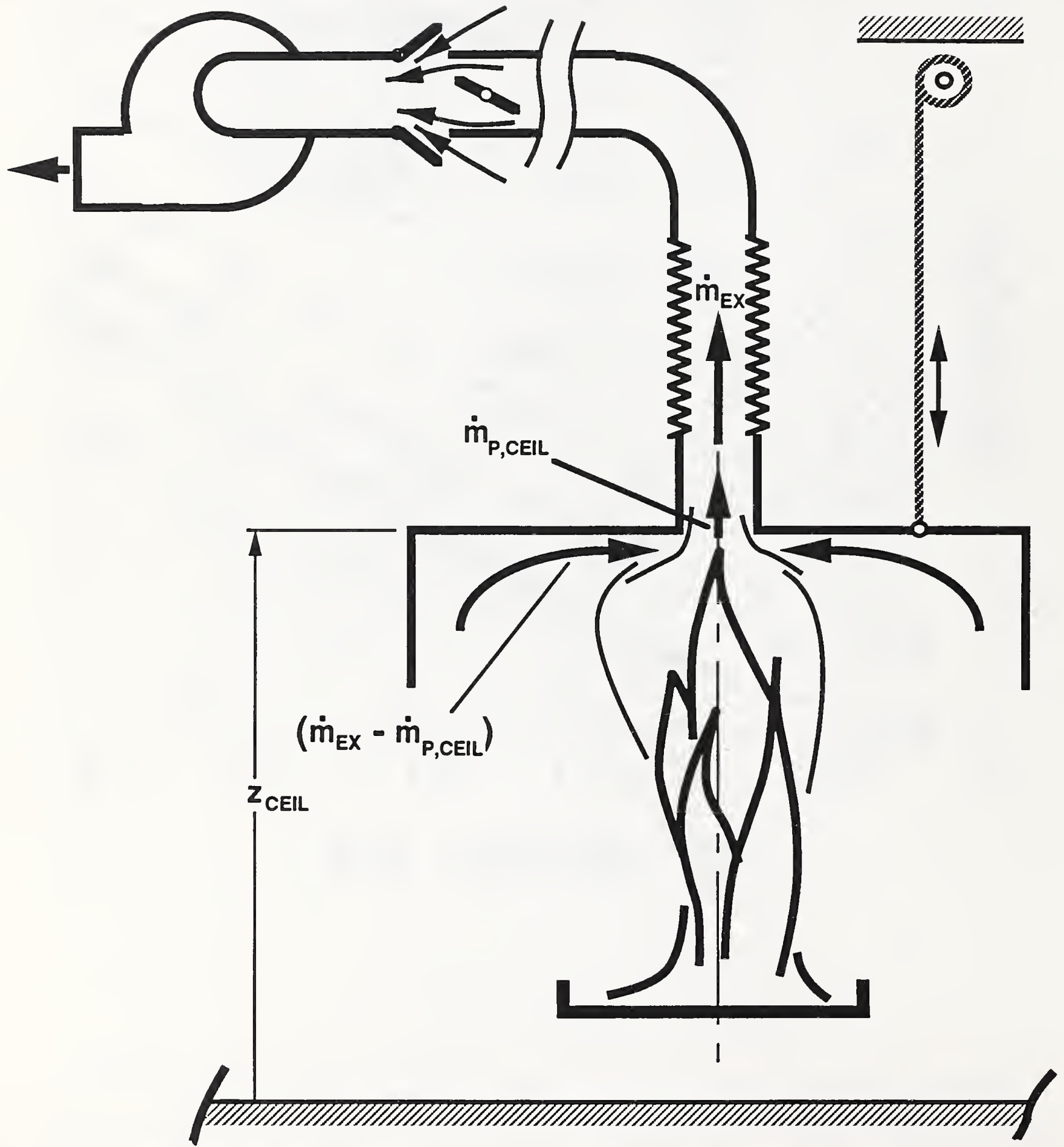

Figure 5. A possible implementation of the ideal hood design concept with variable- $z_{\mathrm{CEIL}}$ and $\dot{\mathbf{m}}_{\mathrm{EX}} \cdot$ 

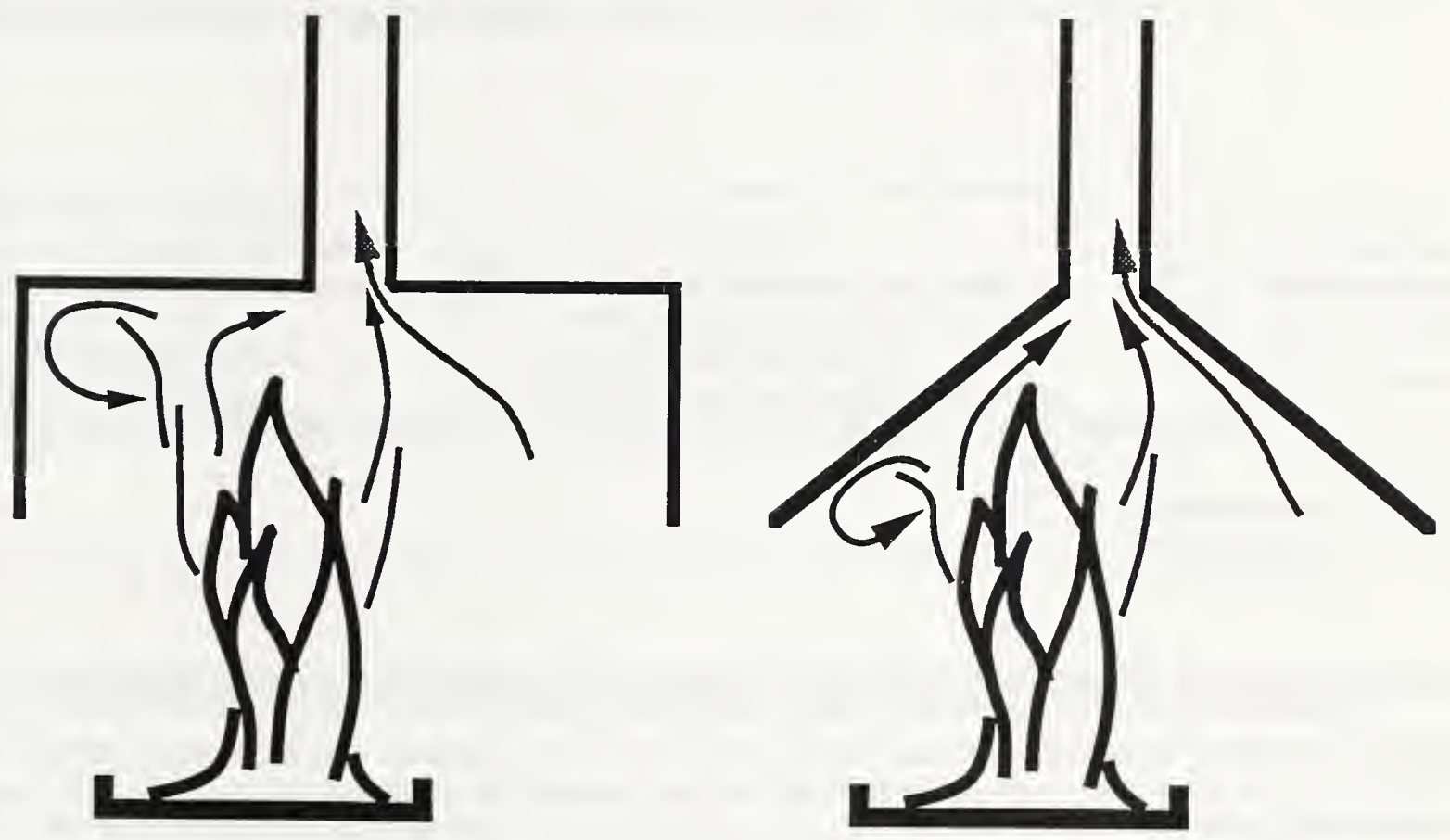

Figure 6. Sketch of the flow for an off-center plume in hoods with identical depth and span and with adequate $\dot{\mathrm{m}}_{\mathrm{EX}} / \dot{\mathrm{m}}_{\mathrm{P}, \mathrm{CEIL}}>1$ to achieve full exhaust of the plume flow, without a smoke-layer: left - horizontal hood ceiling with side-walls; right - conical hood. 

NIST-114

(REV. 9-92)

ADMAN 4.09
U.S. DEPARTMENT OF COMMERCE NATIONAL INSTITUTE OF STANDARDS AND TECHNOLOGY

MANUSCRIPT REVIEW AND APPROVAL

\begin{tabular}{|l|l|}
\hline \multicolumn{3}{|c|}{ (ERB USE ONLY } \\
\hline ERB CONTROL NUMBEA & DIMSION \\
\hline $\begin{array}{l}\text { PUBLCATION REPORT HUMBER } \\
\text { NISTIR 5298 }\end{array}$ & CATEGORY CODE \\
\hline $\begin{array}{l}\text { PUBLCATION DATE } \\
\text { DeC CMbE } 1993\end{array}$ & NUMBER PAINTED PAQES \\
\hline
\end{tabular}

Decent

INSTRUCTIONS: ATTACH OAIGINAL OF THIS FORM TO ONE (1) COPY OF MANUSCAIPT AND SEND TO: THE SECRETARY, APPROPRIATE EDITORIAL REVIEW BOARD. TITLE AND SUBTITLE (CITE IN FUU)

\section{SOME FACTORS AFFECTING THE IESIGN OF A FURNITURE CALORIMETER HOOD AND EXHAUST}

\section{CONTRACT OR GRANT NUMBER}

\section{TYPE OF REPORT AND/OR PERIOD COVERED}

AUTHOR(S) (LAST NAME, FIRST INITIAL, SECOND INITIAL)

Cooper, L. Y.

LABORATORY AND DIVISION NAMES (FIRST NIST AUTHOR ONLY

SPONSORING ORGANIZATION NAME AND COMPLETE ADDRESS (STREET, CITY, STATE, ZIP)

\section{RECOMMENDED FOR NIST PUBUCATION}

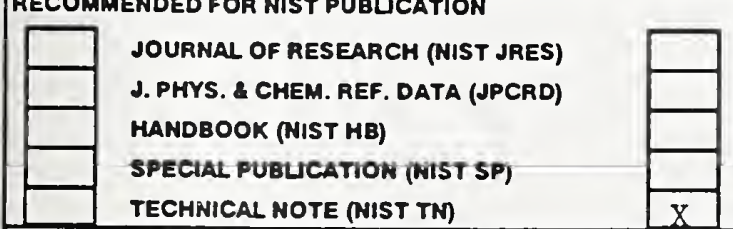

RECOMMENDED FOR NON-NIST PUBUCATION (CITE FULIV

\section{MONOGRAPH (NIST MH)}

NATL STD. REF, DATA SERIES (NIST MSRDS)

FEDERAL INF. PAOCESS. STOS. (NIST FIPS)

UST OF PUBUCATIOHS (NIST LP)

NIST INTERAGENCY/INTERNAL REPORT (NISTIR)
PERFORMING ORQANIZATION (CHECK $(X$ ) ONE BOX)

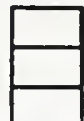

MIST/OATTEERSBURG

NIST/BOULDER

JILA/BOULEER
U.S.
FOREION
LETTER CIRCULAR

BUILDING SCIENCE SERIES

PRODUCT STANDARDS

OTREA

$\mid \begin{aligned} & \text { PUBUSHIMG MEDIUM } \\ & \begin{array}{l}\text { PAPER } \\ \text { DISKETTE (SPECIF } \\ \text { OTHER (SPECIFM }\end{array}\end{aligned}$

SUPPLEMENTARY NOTES

ABSTRACT (A 1500-CHARACTER OR LESS FACTUAL SUMMARY OF MOST SIGNIFICANT INFORMATION. IF DOCUMENT INCLUDES A SIGNIFICANT BIBUOGAAPHY OR UTERATURE SURVEY, CITE IT HERE. SPELL OUT ACRONYMS ON FIRST REFERENCE.) (CONTINUE ON SEPARATE PAGE, IF NECESSARY.)

This work considers factors affecting the design of an effective and versatile furniture calorimeter hood and exhaust system. The purpose of the furniture calorimeter, design functions, and inherent limitations of a particular design are discussed. The interactions between the hood structure and the fire and its plume are analyzed in the context of avoiding: flame impingement on the hood; enhanced combustion of a test article, over and above that of a free-burn; loss of combustion product plume gases due to "spill-over" below the hood; unacceptable dilution of plume gases in the measurement section of the exhaust duct. The concept of the ideally designed hood is introduced, where, throughout the course of the burn of a test article the hood is always immediately above the flame tip and the exhaust rate always exactly matches the hood-ceiling-elevation plume-flow rate. Methods to partially or completely achieve the ideal design are presented. These include the combined features of adjustable hood elevation and adjustable hood exhaust rate.

The ideas and results of analyses developed are applied in examples relevant to the existing furniture calorimeter hood and exhaust system of the NIST Fire Research Laboratory Building 205. Recommendations for improvements to this facility are presented.

KEY WORDS (MAXIMUM 9 KEY WORDS; 28 CHARACTERS AND SPACES EACH; ALPHABETICAL ORDER; CAPITALZE ONLY PROPER NAMES)

buoyant plumes, calorimeters, exhaust systems, fire plumes, flame length, furniture calorimeter, wall flows

\section{AVAILABILTY}

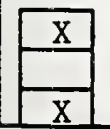

UNUMITED

FOR OFFICIAL DISTRIBUTION. DO NOT RELEASE TO NTIS. ORDER FROM SUPERINTENDENT OF DOCUMENTS, U.S. GPO, WASHINGTON, D.C. 20402 ORDER FROM NTIS, SPRINGFIELD, VA 22161
NOTE TO AUTHOR(S) IF YOU DO NOT WISH THIS MANUSCRIPT ANNOUNCED BEFORE PUBUCATION, PLEASE CHECK HERE. 

